\title{
Políticas e práticas de gestão ambiental: uma análise da gestão dos resíduos da construção civil na cidade de Belo Horizonte (MG)
}

\author{
Polices and Practices of Environmental Management: An Analysis of waste mana- \\ gement in civil construction in the City of Belo Horizonte - MG
}

\author{
Paulo José Silva' \\ Mozar José de Brito² \\ Maria Cecilia Pereira ${ }^{3}$ \\ Robson Amâncio ${ }^{4}$
}

\begin{abstract}
Resumo
Este artigo tem por objetivo estudar as práticas de gestão de resíduos da construção civil implementadas pelo poder público municipal na cidade de Belo Horizonte (MG). Para isso, empregou-se o método de estudo de caso articulado com o processo de triangulação das técnicas de coleta de dados. A natureza da problemática estudada exigiu a sistematização de um quadro de referências que inclui algumas reflexões teóricas sobre a relação entre Estado, políticas públicas e gestão ambiental. A análise dos resultados evidencia que o poder público da cidade de Belo Horizonte articulou e implementou um conjunto de políticas e práticas de gestão dos resíduos da construção que deu origem a uma rede de políticas que envolve a participação de diversos atores sociais públicos e privados. Trata-se de uma configuração institucional com um padrão de relações interdependentes que servem de referência para a concretização das práticas de gestão de resíduos da construção civil. Os resultados deste estudo apontam também os benefícios econômicos, sociais e ambientais, além das dificuldades relativas ao processo de institucionalização das referidas políticas e práticas.
\end{abstract}

Palavras-chave: Políticas Públicas, Gestão Ambiental, Redes de Políticas, Resíduos da Construção Civil.

\begin{abstract}
This paper aims to study the practices of waste management in civil construction implemented by the municipal government of the city of Belo Horizonte- MG. The method used was a case study articulated to the process of triangulation of the techniques of data collection. The nature of the problematic studied demanded the systematization of a frame of references that includes some theoretical reflections concerning the relation between State, public policies and environmental management. The analysis of the results reveal that the municipal government of the city of Belo Horizonte articulated and implemented a set of policies and practices of waste management in civil construction that created a policy network that involves the participation of diverse public and private social actors. It is an institutional configuration with an interdependent standard that serves as a reference for the establishment of the practices of waste management in civil construction. The results of this work also point out the economic, social and environmental benefits and the difficulties related to the process of institutionalization of the practices and policies of environmental management.
\end{abstract}

Keywords: Public Politics, Environmental Management, Policy Networks, Wastes of the Civil Construction.

\footnotetext{
${ }^{1}$ Doutorando em Administração pela Universidade Federal de Lavras. Endereço: Universidade Federal de Lavras - Caixa Postal 37, Campus Universitário, Lavras/Minas Gerais. Brasil - CEP: 37200000 - E-mail: paulojoses@uol.com.br.

${ }^{2}$ Doutor em Administração pela Universidade de São Paulo. Professor do Departamento de Administração e Economia da Universidade Federal de Lavras. Endereço: Universidade Federal de Lavras, Caixa Postal 37, Campus Universitário, Lavras/Minas Gerais - Brasil- CEP: 37200000 . E-mail: mozarjdb@ufla.br.

${ }^{3}$ Doutoranda em Administração pela Universidade Federal de Lavras. Endereço: Universidade Federal de Lavras, Caixa Postal 37, Campus Universitário, Lavras/Minas Gerais. CEP: 37200000. E-mail: cecilia@navinet.com.br.

${ }^{4}$ Doutor em Ciências Sociais, Docente do PPGA - UFLA. Professor do Programa de Pós-Graduação em Administração da UFLA. Endereço: Universidade Federal de Lavras, Caixa Postal 37, Campus Universitário, Lavras/Minas Gerias - Brasil - CEP: 37200000. E-mail: ramancio@ufla.br.

Artigo recebido em setembro de 2005 e aceito para publicação em janeiro de 2006.
} 


\section{Introdução}

Os problemas ambientais têm uma estreita relação com diversos fatores macroeconômicos e sociais, como, por exemplo, o crescimento populacional, a desigualdade na distribuição de renda, aspirações por um estilo de vida mais urbano e materialista, adoção de processos de industrialização intensivos de recursos naturais e geradores de resíduos poluidores, além do consumismo associado a elevados níveis de desperdício (EGRI e PIFIELD, 1998). Nesse sentido, os padrões de consumo da sociedade atual provocam uma retirada de recursos do meio natural maior que sua capacidade de regeneração e uma produção de resíduos maior que sua capacidade de absorção. Como resultado desse desequilíbrio ambiental, cresce a poluição atmosférica, a agressão à camada de ozônio, as mudanças climáticas, e é cada vez maior a geração de resíduos sólidos, principalmente, nos grandes centros urbanos, onde ocorre uma concentração populacional e uma aglomeração de sistemas produtivos cujas atividades causam forte impacto no meio ambiente.

Embora a produção de resíduos sólidos fosse alvo das preocupações de ambientalistas e pesquisadores, foi nas últimas duas décadas que as inquietações políticas e científicas desses autores quanto ao problema se intensificaram, ao mesmo tempo em que a problemática socioambiental ganhou maior destaque, tanto na mídia quanto no meio acadêmico. O movimento ambientalista brasileiro, ao cumprir o seu papel político, tem contribuído de forma significativa para a construção daquilo que muitos autores denominam de "consciência ecológica". A tônica dessa consciência ecológica tem sido a busca pela melhoria da qualidade de vida e o esforço pela preservação dos recursos naturais, bem como o exercício de maior pressão política sobre os poderes Executivo e Legislativo para que criem um marco regulatório e estabeleçam políticas públicas que disciplinem e orientem a intervenção nos espaços socioambientais urbanos.

Mesmo diante do crescente conhecimento sobre gestão ambiental e da maior pressão exercida pela sociedade e pelo Estado (através da legislação), diversos atores das cadeias produtivas, como os da indústria da construção civil, continuam depositando indiscriminadamente os resíduos de suas atividades. Em Belo Horizonte, cerca de $42 \%$ dos resíduos coletados é entulho oriundo da construção civil, uma indústria de elevado potencial poluidor. $\mathrm{Na}$ tentativa de reduzir o impacto que isso causa ao meio ambiente, desde meados da década de 1990, a prefeitura vem formulando políticas públicas e implementando um conjunto de práticas de gestão ambiental

Como já foi dito, este artigo tem por objetivo investigar as práticas de gestão de resíduos da construção civil implementadas pelo poder público municipal em Belo Horizonte. Mais particularmente, pretende-se investigar as especificidades das práticas de gestão pública ambiental adotadas, enfocando as diretrizes políticas que as orientam e as suas contribuições ambientais, sociais e econômicas.

\section{A indústria da construção civil e a produção de resíduos sólidos}

A indústria da construção civil é um dos setores da economia brasileira que se destacam econômica e socialmente pela sua participação no Produto Interno Bruto (PIB) e por ser considerada uma indústria geradora de emprego e renda. Entre 1980 e 1996 essa indústria respondeu por $65 \%$ da formação do investimento bruto nacional, e em 2001 foi responsável por cerca de 15,6\% do PIB. Essa cadeia produtiva tem sido responsável também por um forte movimento de inclusão social, por meio da geração direta e indução indireta de cerca de 14 milhões de empregos (EPUSP, 2002).

No estado de Minas Gerais, em 2003, a indústria da construção civil participou com 22,9\% na composição da atividade industrial (FUNDAÇÃO JOÃO PINHEIRO, 2004a). A sua participação no PIB total do estado fora de 11,68\% em 2001, 10,88\% em 2002 e 9,91\% no primeiro trimestre de 2003 (FUNDAÇÃO JOÃO PINHEIRO, 2004b), empregando cerca de 129.000 pessoas somente na Região Metropolitana de Belo Horizonte (FUNDAÇÃO JOÃO PINHEIRO, 2004a), onde, em 2002, havia 4.537 empresas que empregavam 66.245 trabalhadores com carteira assinada. Em 1999, a indústria da construção civil contribuíra com $6,08 \%$ do PIB total da cidade (BELO HORIZONTE, 2005).

Apesar da sua relevância econômica e social, as estatísticas evidenciam que essa indústria apresenta um elevado potencial poluidor devido ao grande volume de resíduos que gera e que é depositado no meio ambiente. A 
geração de resíduos sólidos por essa indústria ocorre através de diversos processos produtivos relacionados com a execução de um empreendimento imobiliário, com a modernização, manutenção e demolição de obras (JOHN, 2000; JOHN e AGOPYAN, 2000). O depósito irregular de resíduos da construção civil tem causado diferentes tipos de impacto com efeitos nocivos à qualidade ambiental. Além dos elevados custos de gestão, esses depósitos irregulares provocam o assoreamento de córregos e nascentes, a obstrução de vias de tráfego e de galerias de escoamento de águas pluviais, trazendo a proliferação de doenças e prejuízos à paisagem local (PINTO, 1999; JOHN, 2000). Para tentar mitigar o impacto ambiental das diversas atividades econômicas, incluindo aquele causado pela indústria da construção civil, os poderes públicos federal, estadual e municipal têm institucionalizado um conjunto de práticas de gestão. que serão objeto de reflexão nas próximas seções deste artigo.

\section{Reforma do Estado, descentralização administrativa e meio ambiente}

No século XVI, o Estado tornou-se, principalmente na Europa, a instituição encarregada de organizar as relações da sociedade. Ao longo do tempo, essa instituição se estruturou, tornando-se um sistema organizado que procura regular as ações de diferentes agentes, sejam eles públicos ou privados (PHILIPPI JR. e BRUNA, 2004). No Brasil, entre as décadas de 1930 e de 1980, o Estado desempenhou um papel relevante nas estratégias de desenvolvimento, assumindo, além da função de agente regulador do sistema econômico e social, uma lógica desenvolvimentista que procurava dotar o país de infra-estrutura e investir em atividades econômicas que hoje, contudo, não são mais consideradas como típicas de Estado. Assim, o Estado foi o principal agente de financiamento de obras de infra-estrutura, cabendo-lhe, portanto, criar as condições necessárias ao processo de desenvolvimento econômico e social (MENEZES, 1997; BARAT, 2001; PEIXOTO et. al, 1999). Nesse período, o país experimentou um ciclo de crescimento econômico traduzido pelo intenso processo de industrialização e pela elevação dos padrões de consumo da população.

Para Pereira (1997) e Peixoto (1999), a intensificação do movimento de globalização econômica que ocorreu a partir da década de 1970, associado à emergência de novas formas de regulação social e de ideologias políticas, colocou em xeque o papel do Estado, que entrou em crise. Para Pereira (1997, p.7), "o Estado transformou-se na principal causa da redução das taxas de crescimento econômico, da elevação das taxas de desemprego e do aumento da taxa de inflação". Trata-se de uma crise que se intensificou na década de 1980, gerando efeitos de natureza fiscal, política e gerencial que perpassavam as instituições públicas brasileiras (PEREIRA, 1998).

A crise do Estado desenvolvimentista abriu espaço para a institucionalização da ideologia neoliberal, a qual defende a lógica do Estado mínimo e do mercado como mecanismos de regulação da economia. Para tanto, tornou-se necessário promover a redefinição do Estado, visando modernizar sua capacidade administrativa, redefinindo assim seu papel regulador e suas funções. Essa reforma, denominada "Reforma do Estado", tornou-se tema central em todo o mundo na década de 1990; reforma que, segundo Pereira (1997; 1998), deveria abarcar quatro problemas centrais: 
- a delimitação do tamanho do Estado;

- a redefinição do papel regulador do Estado;

- a recuperação da governança ou capacidade financeira e administrativa de implementar as decisões políticas tomadas pelo governo; e

- o aumento da governabilidade ou capacidade política do governo de intermediar interesses, garantir legitimidade e governar.

Para esse autor, a reforma do Estado seria necessária para a consolidação do ajuste fiscal do Estado brasileiro e responsável pela implementação dos princípios da administração pública gerencial, provedora de serviços públicos modernos, profissionais e eficientes, que deveria, em tese, atender às necessidades dos cidadãos. Na visão de Peixoto (1999), com a referida reforma ,tinha-se como meta reduzir custos públicos e buscar maior eficiência administrativa pela aplicação de uma estratégia de gestão por resultados marcada pela inovação, foco no cliente-cidadão e descentralização administrativa. Todavia, a descentralização da ação estatal não é algo que emerge com a proposta de reforma do Estado dos anos 1990, mas, ao contrário, esse princípio sempre esteve presente em outras propostas de mudança do aparelho estatal. A descentralização é um processo de transferência de poder dos níveis centrais para os periféricos. Difundiu-se dos países capitalistas avançados para aqueles do mundo subdesenvolvido, constituindo-se num princípio ordenador de reformas do setor público (MELO, 1996). Trata-se, segundo Junqueira, L. (1998), de um processo que amplia as possibilidades de transferir o poder de decisão sobre as políticas públicas para o âmbito do município.

A Constituição Federal de 1988, ao procurar criar as condições institucionais para o processo de redemocratização das instituições brasileiras, adotou um aparato jurídico que marca a ruptura da lógica autoritária do Estado, abrindo espaço para a descentralização administrativa e para a prática de uma gestão pública mais democrática das cidades. A nova Carta atribuiu novas responsabilidades aos municípios, no que se refere à promoção de programas e políticas públicas visando à melhoria da qualidade de vida nas cidades, até então, centralizadas no governo federal. A autonomia outorgada pela Carta Magna aos municípios estimulou a formulação de diversas políticas públicas no âmbito local.

A possibilidade dos municípios elaborarem suas próprias leis orgânicas facilitou a inserção do planejamento na sua realidade política e socioambiental. Com isso, cada vez mais, vem ocorrendo um convencimento dos governantes de que a esfera local é o lugar mais apropriado para a prática de uma gestão ambiental mais efetiva e participativa, capaz de reverter o atual quadro caótico verificado na maioria das grandes cidades brasileiras, mediante um novo modelo de desenvolvimento urbano, político, econômico, social e ambientalmente sustentável (MENEZES, 1997).

Segundo Silva (1992), proteger o meio ambiente, do ponto de vista municipal, pode significar, dentre outras ações:

- a escolha inteligente dos materiais e desenhos das redes e sistemas de serviços públicos;

- a penalização dos despejos poluentes de estabelecimentos industriais;

- a edição de leis claras, simples e abrangentes sobre poluição, uso e ocupação do solo urbano;

- a criação de espaços territoriais especialmente protegidos;

- a promoção de campanhas de coleta seletiva e reciclagem de lixo; e

- mudança de práticas na administração pública.

Além disso, a administração municipal deve estar atenta para a integração de cada um de seus órgãos administrativos, para que haja uma sintonia de propósitos, valores e princípios, bem como se desenvolvam instrumentos legais, na forma de planos diretores ambientalmente compatíveis e leis urbanísticas com forte conteúdo preservacionista. As políticas e práticas de gestão ambiental municipal devem assentar-se, segundo Junqueira, R. (1998) e Pelicioni (2004), em diagnósticos que levem em consideração as especificidades e saberes locais e que apontem soluções inovadoras para os problemas ambientais vivenciados pelos municípios. 


\section{Políticas públicas, gestão ambiental e relações público-privadas}

A compreensão da natureza das práticas de gestão dos resíduos da construção civil implementadas pelo poder público do município de Belo Horizonte requer o desenvolvimento de uma reflexão teórica pautada pelos conceitos de policy networks, gestão ambiental pública e relações público-privadas. O termo policy network foi cunhado na década de 1970 por cientistas políticos que pretendiam desenvolver formulações teóricas que servissem de referência para a análise de políticas públicas. Em outros termos, a policy network foi definida por Bözel (1998) como uma abordagem teórica que pode servir de referência para a interpretação e análise das relações de troca institucionalizadas entre o Estado e organizações da sociedade civil, do papel desempenhado pelos atores privados e públicos e das relações formais e informais entre eles. Trata-se de uma abordagem teórica que foi simultaneamente desenvolvida por estudiosos ingleses e alemães, dando origem, segundo Börzel (1998), a duas diferentes escolas:

- a interest intermediation school - que interpreta a policy networks como um termo genérico que pode ser empregado para explicar as diferentes formas de relações entre grupos de interesse e o Estado; e

- a governance school - que concebe a policy networks como uma forma específica de governança, como um mecanismo de mobilização de recursos políticos em situações nas quais esses recursos são bastante dispersos entre atores públicos e privados.

Para Börzel (1998), não existe uma demarcação conceitual clara entre essas duas correntes. Contudo, há uma diferença principal entre elas. Enquanto a interest intermediation school concebe a policy networks como um conceito genérico empregado para a compreensão de todos os tipos de relações entre atores públicos e privados, a governance school, ao contrário, defende que essa abordagem deve ser empregada na análise de formas específicas de interação público-privada, cuja coordenação assume uma natureza não-hierárquica.

A policy networks tem sido apontada por diversos autores (FREY, 2000; KLIJN, 1998; LUCHINI, SOUZA e PINTO, 2003; MILLER, 1994; TEIXEIRA, 2002; THATCHER, 1998) como uma abordagem teórica relevante para a compreensão das políticas públicas e das práticas de gestão a elas associadas. Para Miller (1994), essa proposta teórica permite uma análise das relações sociais recorrentes que sejam suficientemente regulares para que ocorra a construção social da confiança e o compartilhamento de valores entre diferentes atores sociais. Seguindo essa mesma linha de reflexão, Thatcher (1998) afirma que o conceito de policy networks apresenta um alto potencial explicativo, especialmente, quando se pretende desenvolver análises de políticas públicas e práticas de gestão que pressupõem a inter-relação entre atores públicos e privados. Em outros termos, essa abordagem tem contribuído significativamente para a compreensão das redes de políticas públicas como padrões mais ou menos estáveis de relações sociais entre atores interdependentes, que tomam forma ao redor dos problemas e/ou dos programas de políticas (KLIJN, 1998). Para esse autor, esse conceito incorpora algumas especificidades que denotam a natureza das redes de políticas; ou seja:

- o fato de que elas existem devido à interdependência entre atores;

- de que nelas atuam diversos atores, cada um com suas próprias metas; e

- de que as redes são relações de natureza mais ou menos duradoura entre atores.

Ao defender a aplicação do conceito de redes de políticas públicas para se compreender a intervenção do Estado, Luchini, Souza e Pinto (2003) afirmam que essa abordagem amplia as possibilidades de avaliação da eficácia das políticas públicas e das práticas de gestão. Essa assertiva também é defendida por Siqueira (2000, p.183), ao afirmar que a abordagem de redes "pode ser importante para descrever as novas e complexas relações decorrentes dos aparatos institucionais e, principalmente, dos múltiplos atores envolvidos nesses processos [...]". Para Pacheco (1999) e Teixeira (2002), essas relações entre múltiplos atores e poder público implicam repensar a organização do próprio Estado, especialmente, no âmbito local, para integrar numa mesma rede, agentes públicos e privados. Essa rede deve ser capaz de catalisar e articular diferentes interesses na busca de novas soluções, bem como, de criar espaços e estabelecer mecanismos de cooperação pública e privada, ampliando, assim, a ação pública em múltiplas dimensões, incluindo a ambiental. Essa dimensão requer a atuação de vários atores sociais no processo de formulação e implementação de políticas e práticas de gestão pública, na 
tentativa de buscar soluções para a problemática ambiental (FERREIRA, 1996). A formação de redes pode também servir de referência para a mobilização de fontes alternativas de financiamento e criação de novos arranjos institucionais que supram a escassez de recursos, promovendo, dessa forma, a cooperação e a integração entre grupos locais e parceiros externos (TOLOSA, 1997).

No Brasil, os problemas ambientais são de tal ordem, que as práticas de gestão ambiental assumem um caráter de bem público (CERQUEIRA, 1992). Para esse autor, embora a gestão ambiental seja um bem público, o Estado não pode assumir isoladamente todas as responsabilidades, ou seja, seria desejável e possível uma gestão ambiental que:

1) seja compartilhada entre o Estado, os diferentes poderes e níveis de governo e os diversos agentes sociais (empresários, sociedade civil etc.);

2) seja descentralizada entre os diferentes níveis de governo (verticalmente) e diferentes setores (horizontalmente), definindo-se funções apropriadas a cada um;

3) seja auto-sustentada financeiramente, o que significa alcançar maior eqüidade na distribuição dos custos. (CERQUEIRA, 1992, p.52).

Essa proposição conceitual aproxima-se daquela formulada por Coimbra (2004, p.561), que define a gestão ambiental como um processo político-administrativo que incumbe o poder público local (Executivo e Legislativo) de, com a participação da sociedade civil organizada, formular, implementar e avaliar políticas ambientais (expressas em planos, programas e projetos), no sentido de ordenar as ações do município, em sua condição de ente federativo, a fim de assegurar a qualidade ambiental como fundamento da qualidade de vida dos cidadãos, em consonância com os postulados do desenvolvimento sustentável, a partir da realidade e das potencialidades locais.

As referidas concepções, além de revelarem os limites da ação do poder público municipal, chamam atenção para a necessidade de se envolver diferentes atores na viabilização de uma gestão ambiental integrada (CALDWELL, 1972, apud FRIEDER, 1997, p.18). A formulação teórica desse autor induz ao resgate do conceito de "gestão ambiental integrada" (IEM - Integrated Environmental Management) cunhada por Margerum (1999) e Margerum e Born (2000). Para Born e Sonzogni (1995), essa estratégia de gestão pode ser vista como uma resposta para grande parte da tradicional gestão de recursos naturais, a qual tem sido largamente reativa, desunida e com propósitos restritos ou limitados. A noção de IEM, além de incorporar valores como confiança, reciprocidade e cooperação, implica não apenas a negociação permanente de divergências, mas também que haja consenso em torno dos interesses que perpassam o conjunto de ações públicas concretizadas por meio da concepção e da implementação de programas e projetos ambientais (MITCHELL, 1986, apud MARGERUM, 1999, p.152). Em outros termos, a noção típica de IEM envolve ações de governo, de organizações nãogovernamentais e de indivíduos, representando um amplo conjunto de interesses e perspectivas de ação pública (MARGERUM e BORN, 2000). Portanto, pode ser observado que a IEM tem por finalidade realizar uma espécie de concerto que possibilite um certo consenso entre os objetivos de desenvolvimento socioeconômico e de preservação da qualidade ambiental, podendo ser aplicada em diferentes níveis de intervenção; ou seja, em escalas local, regional, continental e global (FRIEDER, 1997).

As práticas de gestão ambiental integrada implicam, necessariamente, promover a interação entre diferentes atores sociais, tais como: cidadãos interessados, representante de grupos de interesses, governo local e agências estaduais e federais. A interação entre esses atores poderá, quando bem mediada, ter dois efeitos positivos:

- o processo ajuda a alcançar os objetivos essenciais da IEM, incluindo uma formação diversificada de informação, conhecimento e perspectivas; e

- pode criar redes, gerar capital social e fomentar a vontade política, necessários para colocar uma proposta integrada em operação.

Para tanto, essa interação requer o desenvolvimento de um processo de coordenação que incorpore duas práticas sociais: a comunicação e a mediação de conflito. A comunicação entre os diferentes atores promove o compartilhamento de informação, de análise, de metas e de objetivos. A mediação de conflito, por sua vez, serve de 
referência para consolidar o consenso em torno da filosofia e das práticas de gestão ambiental marcadas pela pluralidade conceptual e política.

As reflexões de Grumbine (1994), Margerum e Born (1995; 2000), Mitchell e Hollick (1993) e Slocombe (1993) demonstram que as práticas de gestão ambiental integrada assumem uma complexidade cuja gênese está vinculada à pluralidade política, que exige a regulação permanente das relações público-privadas. No âmbito municipal, essas práticas devem levar em consideração as dimensões econômica, social, cultural e ambiental. Isso inclui o fortalecimento de cooperações intermunicipais e a participação da população na definição de prioridades associadas às práticas de gestão ambiental que devem envolver o planejamento, o controle, o acompanhamento e a comunicação permanentes (NUNESMAIA, 2000). Para Demajorovic (1994) e Jacobi (2000), essas linhas de ações devem ser articuladas com políticas sociais municipais. Assim, as práticas de gestão ambiental integrada podem se tornar mecanismos de mediação na construção da cidadania, na ampliação da consciência política da população e na geração de emprego e renda, desde que:

- envolvam a participação dos setores público e privado e das populações locais, dentre outros atores;

- considere os aspectos socioculturais e o saber local;

- desenvolva o sentido de responsabilidade social e ambiental; e

- respeite os limites estabelecidos pela legislação vigente que regula a questão ambiental nos âmbitos local, estadual e federal.

Dos resultados positivos dessas práticas de gestão ambiental, destacam-se aqueles que promovem a inclusão social de camadas populacionais marginalizadas através da geração de empregos, o aumento da consciência ambiental, a ampliação e fortalecimento da co-responsabilidade da sociedade na fiscalização e controle dos agentes responsáveis pela degradação socioambiental e a redução do impacto ambiental causado pelas atividades econômicas, no caso específico deste trabalho, as atividades da construção civil.

\section{Procedimentos metodológicos e natureza da pesquisa}

A natureza do fenômeno social tem sido apontada por alguns autores como um elemento marcante na decisão dos pesquisadores sobre o método de pesquisa a ser empregado para a compreensão de qualquer realidade social (BRITO, 2000). Assim, para o entendimento das práticas de gestão de resíduos da construção civil implementadas pelo poder público da cidade de Belo Horizonte e suas múltiplas dimensões, optou-se por realizar uma pesquisa de natureza qualitativa (BOGDAN e BIKLEN, 1994; LAVILLE e DIONNE, 1999). Para tanto, partindo do pressuposto de que a condução de uma pesquisa acadêmica é um processo de construção e reconstrução analítica, este estudo procurou:

- apreender a visão de diversos atores sociais envolvidos nas práticas de gestão em questão. Portanto, trata-se de uma pesquisa acadêmica que inclui diferentes olhares sobre o mesmo fenômeno;

- centrar a atenção em diversos aspectos que circunscrevem a realidade investigada, tais como, marco regulatório, políticas públicas, processo de reciclagem e repercussões socioeconômicas e ambientais associadas às práticas de gestão dos resíduos oriundos das atividades de construção civil em Belo Horizonte;

- seguir fielmente o protocolo da pesquisa qualitativa, dialogando com os construtores da realidade investigada, para apreender sua lógica de interpretação e compreensão acerca do fenômeno estudado. À medida que se interagia com os informantes da pesquisa, procurou-se identificar aspectos relevantes para a construção de um mosaico analítico que retratasse a realidade definida como objeto de estudo;

- não formular a priori nenhuma hipótese sobre a realidade que foi investigada. Em vez disso, construir uma proposta de análise a partir do diálogo estabelecido entre a revisão teórica e a observação sistemática da realidade, como recomendam os defensores dos métodos de pesquisa qualitativa (ALENCAR, 2000; BOGDAN e BIKLEN, 1994). 
Desse modo, optou-se pelo método de pesquisa descritiva que permite desenvolver um processo analítico que considera diferentes interpretações dos diversos atores sociais envolvidos com o fenômeno objeto da investigação (BOGDAN e BIKLEN, 1994). Acredita-se que essa escolha metodológica produza explicações sobre as práticas de gestão de resíduos em questão, e que sirva de referência para a assimilação do contexto públicoprivado (LAVILLE e DIONNE, 1999) em que as mencionadas práticas estão inseridas; ou seja, o universo da pesquisa.

\section{Universo da pesquisa}

Neste artigo, o município de Belo Horizonte foi considerado como universo da pesquisa de campo, representado pela Secretaria de Limpeza Urbana (SLU), incluindo sua sede, os locais apropriados para coleta de resíduos da construção civil e as duas usinas de reciclagem de entulho. A cidade de Belo Horizonte foi escolhida para ser objeto de análise por implementar de forma pioneira, há mais de 10 anos, um conjunto de práticas de gestão dos resíduos oriundos das atividades da construção civil. A experiência vivenciada pela referida cidade recebeu vários prêmios e poderá ser reproduzida em outros municípios (individualmente ou na forma de consórcios), desde que respeitadas as especificidades locais, o estágio de desenvolvimento local, aspectos socioculturais de sua população, a disponibilidade de recursos e os interesses públicos e privados associados às práticas de gestão ambiental.

\section{Procedimentos de coleta de dados}

A definição das linhas demarcatórias do trabalho empírico e a escolha das técnicas de coleta de dados representam um passo importante na consolidação do rigor científico exigido pelo mundo acadêmico para qualquer atividade relacionada à pesquisa científica (BRITO, 2000). Para garantir esse rigor, foi desenvolvido um protocolo científico orientado pela lógica da triangulação; ou seja, pela aplicação combinada de diversas técnicas de coleta de dados no período de junho 2004 a maio de 2005. Acredita-se que a aplicação simultânea de diversas técnicas - análise documental, observação sistemática (visitas) e entrevistas semi-estruturadas - permitiu atingir a profundidade e amplitude que marcam os estudos de casos.

A triangulação de diversos procedimentos da coleta de dados foi divida em cinco etapas. Na primeira, foi feita uma pesquisa documental sobre o marco regulatório da política ambiental brasileira, enfocando as políticas que regulavam as práticas de gestão de resíduos da construção civil. Esse procedimento também possibilitou uma leitura cronológica das principais medidas adotadas pelo poder público para tentar mitigar o impacto ambienta.

Na segunda etapa, após um contato inicial com os técnicos responsáveis pelo Programa de Correção das Deposições Clandestinas e Reciclagem de Entulho ${ }^{5}$ da Prefeitura Municipal de Belo Horizonte, optou-se por fazer uma visita técnica que serviu de referência para a obtenção dos primeiros registros sobre a realidade pesquisada. Foram visitadas a sede da Superintendência de Limpeza Urbana (SLU), a usina de reciclagem de entulho no bairro Estoril, duas unidades de recebimento de pequenos volumes (URPV) e obras da prefeitura em que eram utilizados os materiais reciclados pelas usinas.

Na terceira etapa, foi realizada outra análise documental de acervos relativos à história da Superintendência de Limpeza Urbana (SLU), bem como de elementos historiográficos a respeito da criação do Programa de Correção das Deposições Clandestinas e Reciclagem de Entulho. Com esse procedimento se procurou identificar as especificidades das políticas públicas e das práticas de gestão ambiental adotadas pelo governo municipal desde a criação do referido programa. Nesse momento, também foram levantados na biblioteca da SLU os documentos referentes à legislação ambiental municipal e os principais dados estatísticos secundários - como o volume de material reciclado, o volume de material recebido pelas URPVs, a composição dos resíduos sólidos da cidade de Belo Horizonte e o número de usuários das URPVs - que demonstravam resultados das práticas de gestão de resíduos implementadas pela superintendência.

\footnotetext{
${ }^{5}$ Neste estudo, esse programa também é denominado apenas "programa de reciclagem de entulho".
} 
$\mathrm{Na}$ quarta etapa, depois de elaborado um roteiro semi-estruturado, a intenção dos autores era fazer 24 entrevistas. No entanto, foram feitas 21 entrevistas com profissionais da SLU responsáveis pelo Programa de Correção das Deposições Clandestinas e Reciclagem de Entulho e outros participantes do programa, como o:

- coordenador do programa;

- engenheiro do Departamento de Projetos Especiais;

- arquiteta da prefeitura, integrante do Departamento de Projetos Especiais;

- secretária adjunta de serviços urbanos da Prefeitura de Belo Horizonte;

- ex-gerente da usina de reciclagem de entulho Estoril;

- ex-gerente da usina de reciclagem de entulho Pampulha;

- ex-diretor técnico do programa;

- ex-coordenador do programa;

- responsável pela frente social do Programa de Correção Ambiental e Reciclagem com Carroceiros;

- sete carroceiros que operam o sistema de coleta de resíduos;

- representante da Ecobloco (fábrica de artefatos de concreto);

- quatro gestores de URPVs.

Como critério para a escolha dos entrevistados, foi considerado seu nível de envolvimento e importância no contexto da pesquisa de campo e ser indicado por um informante já entrevistado. Decidiu-se por entrevistas semi-estruturadas, por serem menos rígidas, no sentido de conservarem certa padronização das perguntas e não imporem opções de respostas (LAVILLE e DIONNE, 1999), permitindo que o entrevistado manifestasse seus pontos de vista (ALENCAR, 2000). Todas as entrevistas foram gravadas com autorização prévia dos entrevistados. Na reprodução das entrevistas deste estudo, foi mantido o linguajar dos entrevistados. Cabe ressaltar que, conforme já mencionado, a intenção inicial dos autores era fazer 24 entrevistas, sendo dez carroceiros e não sete. Entretanto, foram entrevistados apenas sete indivíduos, não sendo entrevistados outros três por opção dos pesquisadores, pelo critério de saturação que leva em consideração a repetição dos dados durante as entrevistas já realizadas. Os carroceiros foram entrevistados em quatro URPVs diferentes, durante as visitas do pesquisador. Pelo fato das entrevistas terem sido feitas no horário de trabalho, os entrevistados foram escolhidos aleatoriamente, ou seja, foi entrevistado o carroceiro que estava no local, durante a visita do pesquisador. Além disso, durante a pesquisa, sistematizou-se uma caderneta de campo na qual eram anotadas as observações do pesquisador, bem como os relatos das pessoas sobre os fatos relacionados com as práticas de gestão ambiental em questão (BOGDAN e BIKLEN, 1994).

Finalmente, na quinta fase do processo de coleta de dados, retornou-se à sede da SLU para novas entrevistas com gestores e levantamento de dados complementares que esclarecessem dúvidas surgidas nas fases anteriores. Esse retorno ocorreu após a sistematização e análise crítica inicial dos dados levantados. É importante observar que esse retorno ao campo foi determinante para a melhoria da qualidade das informações que serão analisadas na próxima subseção.

\section{Plano de análise dos resultados da pesquisa de campo}

Os resultados desta pesquisa foram analisados com base no quadro teórico sistematizado para este estudo, que inclui um conjunto de reflexões sobre a relação entre Estado, políticas públicas e gestão ambiental. Para tanto, concluídas as etapas anteriormente mencionadas, começou a sistematização das informações coletadas e a análise das entrevistas. Esse procedimento envolveu:

- uma pré-análise - com a organização e sistematização das informações obtidas nas entrevistas e constituição do corpus de linguagem, levando em conta os critérios de exaustão, recorrência de temas, dualidades, contradições e pertinência; 
- a exploração em profundidade das informações relevantes para a compreensão das políticas e práticas de gestão ambiental em questão; e

- o tratamento e interpretação dos resultados da pesquisa. Esse último processo incluiu uma análise das particularidades das práticas de gestão ambiental dos resíduos da construção civil implementadas pelo poder público municipal e dos benefícios econômicos, sociais e ambientais delas decorrentes.

\section{As práticas de gestão ambiental de resíduos da construção civil na cidade de Belo Horizonte}

\section{Origem, diretrizes políticas e rede municipal de coleta de resíduos}

A Superintendência de Limpeza Urbana foi criada pela Lei no 2.220 de 27-8-1973, como autarquia municipal, com a finalidade de prestar serviços de varredura, coleta, depósito, tratamento e transformação de lixo em todo o município de Belo Horizonte (BELO HORIZONTE, 2005). Além disso, a SLU tem um departamento específico (Departamento de Programas Especiais) criado recentemente, que é responsável pela coleta seletiva, pelo Programa de Correção das Deposições Clandestinas e Reciclagem de Entulho e outros projetos específicos da área.

O Programa de Correção Ambiental começou em 1993 quando a superintendência contratou uma consultoria para avaliar as condições de deposição do entulho da construção civil na cidade. Essa consultoria constatou que Belo Horizonte apresentava 134 pontos de deposição clandestina de entulho e uma geração média de $425 \mathrm{~m}^{3}$ de entulho e terra por dia, gerando uma despesa para o orçamento da prefeitura de US $\$ 1.070 .000$ por ano com a remoção desse entulho. O diagnóstico da consultoria demonstrou também a necessidade de se implantar quatro estações de reciclagem e 12 unidades de recebimento de pequenos volumes (URPVs) para suprir esse volume de resíduo gerado. Essa constatação estimulou a Prefeitura de Belo Horizonte a formular e implementar uma política municipal de gestão integrada dos resíduos da construção civil que envolve:

- a regulamentação da política municipal de resíduos da construção civil;

- um plano integrado de gerenciamento desses resíduos; e

- projetos específicos para esse gerenciamento.

Essa política pública municipal pauta-se pelos seguintes princípios e diretrizes:

- criação de uma infra-estrutura urbana de coleta, triagem e reciclagem de resíduos da construção civil, contribuindo, assim, para a redução das deposições clandestinas que causam impacto ao meio ambiente;

- promover a formação de parcerias entre diversos atores (públicos e privados), pautadas pela confiança e cooperação, visando melhorar a eficiência do processo de gestão dos resíduos, reduzir os custos de operação e estimular o aproveitamento de competências instaladas;

- promover a educação ambiental visando elevar o nível de conscientização de diversos tipos de público interessados, tais como, construtoras, coletores e transportadores de resíduos, poder público e cidadãos, dentre outros; e

- promover a inclusão social por meio da geração de emprego e renda, levando em consideração processos de destinação e reciclagem de resíduos da construção civil que sejam compatíveis ambientalmente.

Para concretizar a referida política, a Prefeitura de Belo Horizonte organizou e implementou, a partir de 1995, duas práticas de combate e prevenção:

- a primeira, denominada "rede receptora do resíduo", envolvendo a implantação das URPVs, das estações de reciclagem de entulho e os aterros municipais de resíduos inertes; e

- a segunda, chamada de rede programática, envolvendo práticas de gestão específicas: educação e informação, recuperação de áreas degradadas e projeto de fiscalização. 
As referidas práticas de combate fazem parte do Programa de Correção das Deposições Clandestinas e Reciclagem de Entulho, implantado com o objetivo geral de promover a correção dos problemas ambientais urbanos gerados pela deposição indiscriminada de resíduos da construção na malha urbana. Mais especificamente, com o programa objetiva-se:

- recuperar áreas degradadas pela deposição clandestina;

- minimizar a ocupação do aterro sanitário com entulho potencialmente reciclável;

- implantar uma rede descentralizada de locais para a deposição dos resíduos de construção;

- produzir material reciclado de boa qualidade para utilização prioritariamente em obras públicas e de interesse social;

- permitir a substituição daqueles materiais convencionalmente empregados na construção civil, prioritariamente, em obras públicas e de interesse social.

Inicialmente, a área identificada como a principal geradora de deposições clandestinas, foi a região oeste de Belo Horizonte. Com isso, o bairro Estoril foi definido como o local mais apropriado para implantação da primeira estação de reciclagem de entulho, a Estação de Reciclagem de Entulho Estoril. Para tal, foi utilizada uma área pública, um antigo "bota-fora" que já era utilizado para deposições clandestinas.

Juntamente com a implantação da primeira estação de reciclagem, ainda em 1995, começaram a ser instaladas as primeiras unidades de recebimento de pequenos volumes. Com o funcionamento bem-sucedido da primeira estação de reciclagem de entulho, a implantação da segunda estação (que já estava prevista) aconteceu em função da demanda da sociedade por esse serviço. Assim, em 1996, foi implantada a Estação de Reciclagem de Entulho Pampulha. No caso do Programa de Correção das Deposições Clandestinas e Reciclagem de Entulho, pode-se observar que ele começou a ser legitimado socialmente a partir da implantação de uma segunda usina de reciclagem, o que atendeu a uma demanda da própria sociedade. Como nos lembra Jacobi (2002), a intencionalidade de qualquer prática de gestão ambiental necessita de um período de amadurecimento para que seja legitimada pela sociedade.

A instalação das referidas estações de coleta e reciclagem deu origem ao processo de consolidação de uma rede receptora de resíduos da construção civil, que passou a integrar outros atores antes considerados poluidores por promoverem a deposição irregular; ou seja, os carroceiros, vistos até então pelo poder público, como degradadores do meio ambiente. Esses atores foram incorporados à rede de coleta como prestadores de serviço de transporte de entulhos (oriundos de pequenas construções ou reformas), evitando, assim, o depósito desse material em locais impróprios. Dessa forma, a partir de 1997, a Prefeitura de Belo Horizonte passou a incorporar os carroceiros ao programa de reciclagem de entulho. Com a integração deles à rede de coleta, ocorreram duas mudanças significativas. Em primeiro lugar, o poder público local substituiu as práticas de coerção pelas de comunicação com esses atores, ampliando assim as possibilidades de diálogo, o que levou ao compartilhamento de metas e objetivos, promovendo uma mediação de conflito, como defende Margerum e Born (1995). Em segundo lugar, a prefeitura procurou incorporar o conhecimento dos carroceiros sobre o processo de coleta dos resíduos, facilitando, assim, as operações da rede receptora e a mudança do papel social desses atores, que deixaram de ser agentes degradadores do meio ambiente para atuarem efetivamente na sua preservação.

Além dos carroceiros, a rede receptora de resíduos criada pelo poder público articula outros atores (figura 1):

Figura 1 Elementos integrantes da rede receptora de resíduos e opções de coleta do entulho 


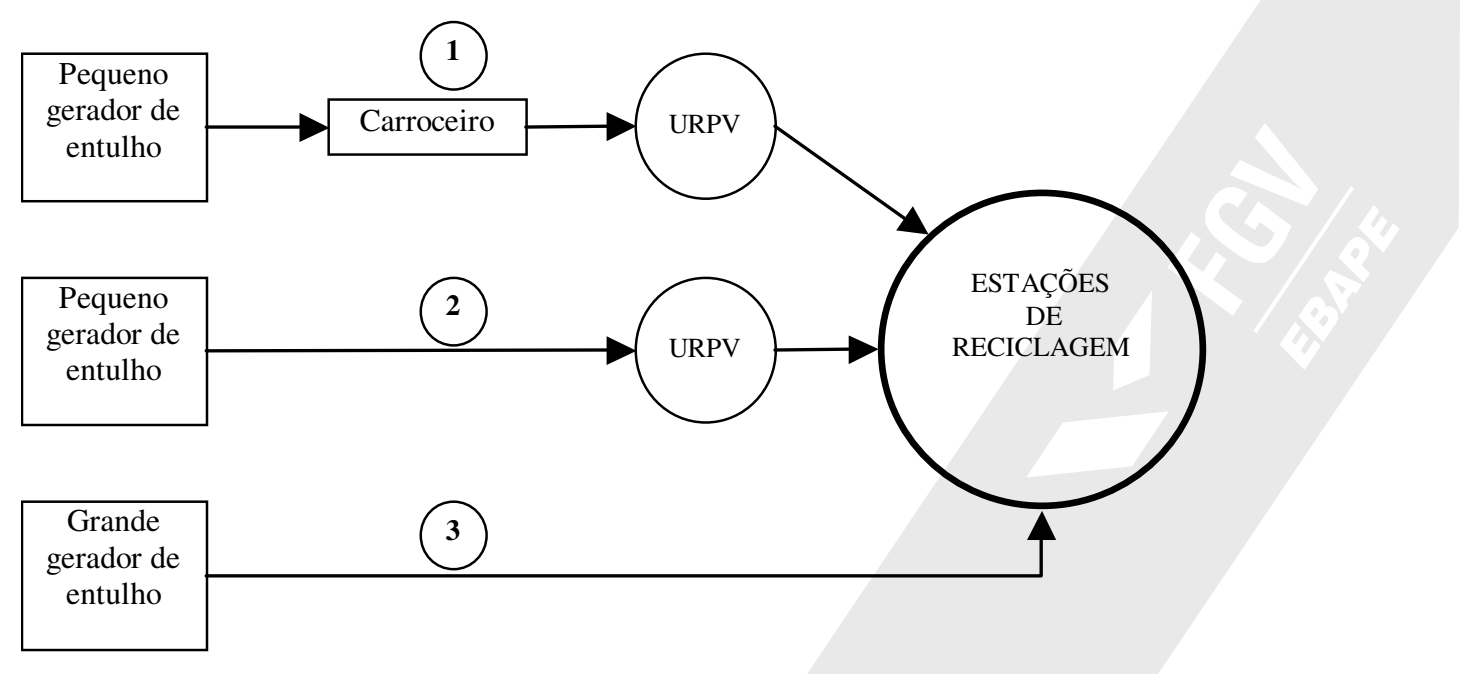

Fonte: elaborado pelos autores.

Pela configuração da rede receptora, verifica-se que a interação entre os agentes anteriormente mencionados leva a três opções de coleta de resíduos:

- opção 1 - o pequeno gerador de entulho (gerador de até $2 \mathrm{~m}^{3} / \mathrm{dia}$ ) liga para o "disque carroça", telefone da prefeitura destinado exclusivamente para contratação do serviço de transporte de entulho através de carroceiros. A ligação é transferida para a URPV mais próxima do pequeno gerador. Ao receber a ligação, o responsável por essa URPV manda um carroceiro ao endereço solicitado. O carroceiro recolhe o material e o transporta para a URPV, onde é separado de acordo com sua natureza. Em seguida, os resíduos da construção civil aptos para reciclagem são levados pela prefeitura para as estações de reciclagem;

- opção 2 - o próprio cidadão pode transportar o material ou entulho do local de geração para a URPV, desde que não exceda $2 \mathrm{~m}^{3} / \mathrm{dia}$. Geralmente, esse transporte é feito por veículos particulares ou, até mesmo, por carrinho de mão;

- opção 3 - o grande gerador de entulho destina o entulho de mais de $2 \mathrm{~m}^{3}$ diretamente para as estações de reciclagem.

Nas estações, antes de serem reciclados, os resíduos passam por um processo de recepção, seleção e classificação, verificando-se sua composição e grau de contaminação. Nesse processo, é considerado adequado para reciclagem o resíduo com até $10 \%$ de impurezas. Por meio da triagem (seleção) desse resíduo, a parcela de material rejeitada (as impurezas) é separada da parcela apropriada para reciclagem e destinada ao aterro sanitário. Posteriormente, o resíduo separado para reciclagem passa por um processo de trituração, mecânico, utilizandose um equipamento de britagem cuja principal função é transformar os resíduos em material (na forma de agregados como areia e minério de ferro) empregado na construção civil. Após esse processo, o material reciclado fica depositado no pátio das estações de reciclagem até que seja expedido para obras da própria prefeitura ou vendido para o mercado da construção civil.

Paralelamente à implementação da infra-estrutura da rede de coleta de resíduos, o poder público municipal formulou e implementou um conjunto de políticas e práticas de comunicação, mobilização social, recuperação de áreas degradadas e de fiscalização ambiental que apresentam as seguintes particularidades:

- comunicação e mobilização social - essa prática tem um caráter educativo, sensibilizador e organizativo, que visa ao envolvimento e à efetiva participação do cidadão na busca de soluções para os problemas decorrentes da geração dos resíduos sólidos. A comunicação consiste na confecção e distribuição de panfletos que orientem, de forma educativa, a população quanto à importância da reciclagem de resíduos sólidos, priorizando, nesse caso, a reciclagem de resíduos da construção civil. A prática de mobilização social é um processo cotidiano que utiliza instrumentos variados como o teatro, a música e a 
dança, aliados às abordagens corpo a corpo junto à população. Durante a implantação de um equipamento de limpeza urbana como URPV ou estação de reciclagem, uma equipe executa um trabalho de campo objetivando a mobilização social do entorno, a conscientização da importância do equipamento, a divulgação do evento e a promoção de palestras. Essa prática de comunicação e mobilização tem por objetivo estimular a participação da população e contribuir para o florescimento de uma nova cultura política (BAVA, 1994).

- recuperação de áreas degradadas - consiste em promover a limpeza dos locais de propriedade pública que, geralmente, são usados para deposições clandestinas. Após a limpeza da área, são implementados espaços urbanos que passam a ser denominados de "Ponto Limpo - Ponto Verde". Esses espaços seguem um projeto paisagístico, que conta com cercamento do local, pintura do meio-fio e jardinagem. A manutenção desses pontos passa pelo processo de conscientização da população local, monitoramento da mobilização social e fiscalização para impedir o retorno das deposições clandestinas. De acordo com a SLU, essa prática inibe a deposição clandestina, reduzindo-se o custo operacional relacionado com a gestão dos resíduos da construção civil. Outra prática adotada pelo poder público para recuperar áreas degradadas e inibir as deposições clandestinas tem sido a construção de campos de futebol. Essa estratégia passou a ser adotada a partir do momento em que os técnicos da SLU constataram que, onde existe um campo de futebol, a população não tem o hábito de realizar deposições clandestinas de resíduos. Por isso, o poder público está formando parcerias para financiar a intensificação da referida prática, evitando, desse modo, as deposições clandestinas.

- monitoramento e fiscalização - essa prática consiste em atuar com os agentes transportadores de resíduos e a população em geral na coibição do lançamento indiscriminado de resíduos. Esse processo de fiscalização apóia-se no Regulamento de Limpeza Urbana (RLU) e em outros instrumentos jurídicos como a Lei Ambiental, o Código de Postura e o Código Sanitário.

Além das referidas políticas e práticas de gestão ambiental, o poder público tem procurado articular a formação de diversas parcerias, cuja finalidade é dar sustentação ao Programa de Correção das Deposições Clandestinas e Reciclagem de Entulho.

\section{As parcerias estruturantes das políticas e práticas de gestão ambiental}

Desde a implementação do Programa de Correção das Deposições Clandestinas e Reciclagem de Entulho, a Prefeitura de Belo Horizonte, através da SLU, tem procurado priorizar as parcerias com empresas, universidades, sindicatos e também entre órgãos da própria prefeitura. A formação dessas parcerias tem por objetivo promover a sustentabilidade econômica, política e social das práticas de gestão ambiental aplicadas ao setor da construção civil local (FARAH, 1997; FERREIRA, 1996; SILVA, 2004; TOLOSA, 1997). Esse processo vem se consolidando com a implementação de parcerias com:

- diversos centros de pesquisa da Universidade Federal de Minas Gerais (UFMG) (Escolas de Engenharia, de Comunicação, de Economia, Instituto de Geociências, Veterinária);

- com o Sindicato da Indústria da Construção Civil;

- com empresas privadas;

- com outras instituições de ensino e pesquisa, como a Escola de Design da Universidade Estadual de Minas Gerais e o Centro Federal de Ensino Tecnológico (Cefet) e

- com outros órgãos e secretarias de governo, como a Superintendência de Desenvolvimento da Capital (Sudecap) - órgão responsável pelo planejamento e execução de obras em Belo Horizonte -, a Empresa de Transporte e Trânsito de Belo Horizonte (BHTrans) e a Secretaria Municipal de Saúde.

Esse arranjo institucional (figura 2) se aproxima de uma policy network que tem um padrão de relações interdependentes, as quais servem de referência para a concretização das práticas de gestão de resíduos da construção civil descritas anteriormente. 


\section{Figura 2}

Rede de política pública de gestão de resíduos da construção civil

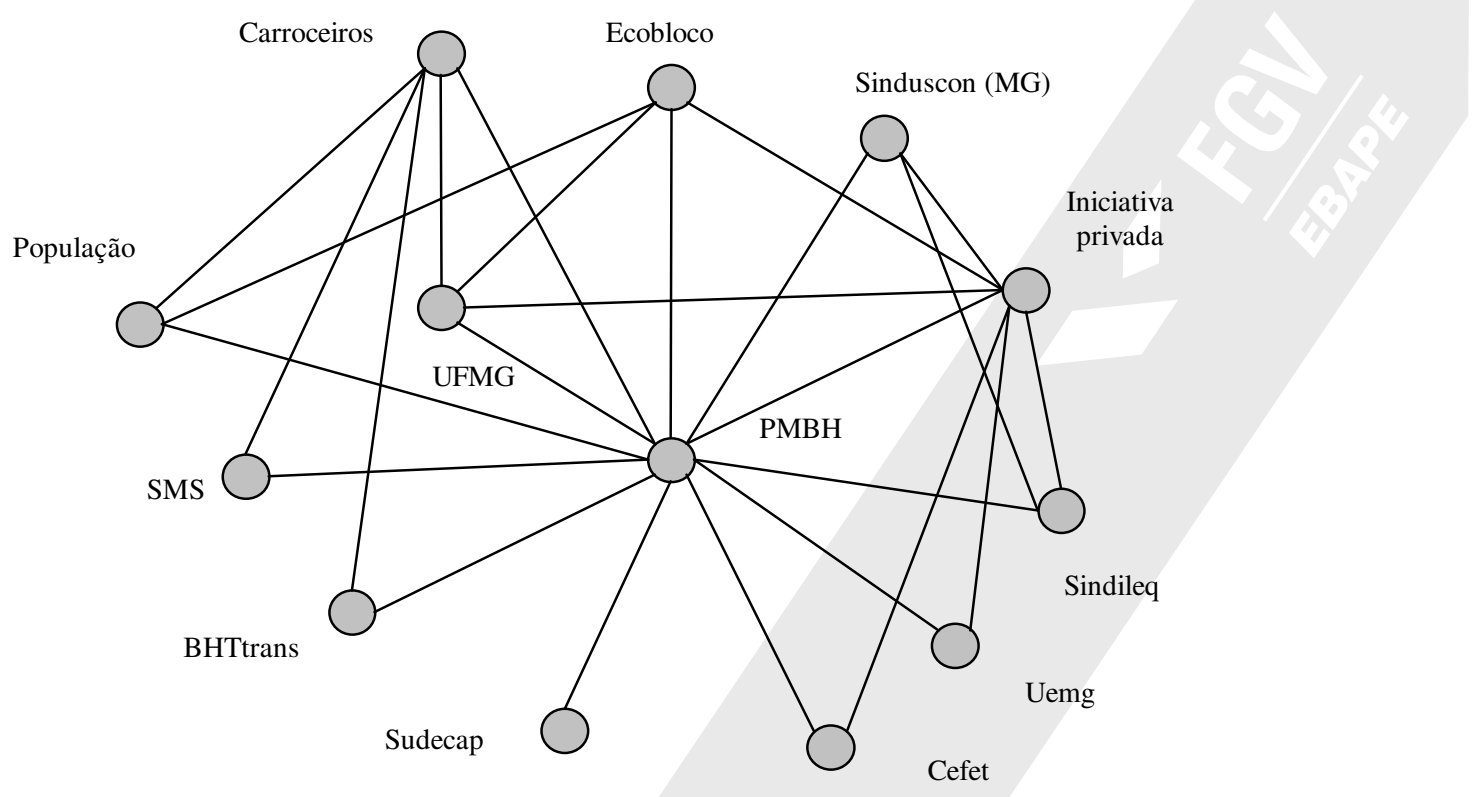

Fonte: elaborado pelos autores.

O processo de governança articulado no âmbito dessa rede tem sido marcado pela informalidade, improvisação e cooperação. Trata-se de um processo pouco formalizado, como pressupõe a policy networks defendida por Miller (1994). Para esse autor, as redes de políticas são marcadas por relações sociais recorrentes, menos formais e limitadas quando comparadas com as relações sociais institucionalizadas. Contudo, as parceria estabelecidas entre o poder público municipal e os diversos atores sociais têm alcançado regularidade suficiente para que se estabeleçam relações de confiança e mútua colaboração, conforme demonstrado adiante.

Foi observado que a formação da referida policy network contribuiu para o aumento da eficácia das políticas e práticas de gestão de resíduos da construção civil (LUCHINI, SOUZA e PINTO, 2003), colocando o poder público municipal como protagonista da articulação entre as organizações governamentais, empresariais e sociais (TEIXEIRA, 2002). Deve ser ressaltado que na institucionalização dessa governança em rede, o poder público local assumiu o papel de catalisador/articulador de forças, privilegiando a construção de espaços e mecanismos de cooperação entre atores públicos e privados (MOURA, 1998).

Por sua vez, a parceria poder público-universidades também produz resultados de mão dupla. As universidades colocam à disposição do poder público um conjunto de conhecimentos técnicos que facilitam o processo de gestão dos resíduos e, em contrapartida, o espaço público serve de laboratório para teste de novos processos e produtos que contribuam para a resolução dos problemas ambientais (CALDWELL, 1992, apud FRIEDER, 1997).

A rede de políticas públicas de gestão ambiental não se concretiza apenas através das parcerias com atores externos ao poder público, mas também, pela interação com outros órgãos integrantes da administração municipal (Secretaria Municipal de saúde, Sudecap, BHTrans) cujas operações, de algum modo, mantêm interfaces com as políticas e práticas de gestão dos resíduos da construção civil (PHILIPPI e BRUNA, 2004). Em outros termos, parcerias com esses órgãos têm por objetivo dinamizar o processo gerencial, para aumentar a probabilidade de resolução dos problemas socioambientais (JUNQUEIRA R., 1998).

Essas e outras parcerias articuladas pelo poder público têm por objetivo consolidar redes, parcerias estratégicas e outros mecanismos de engenharia institucional que contribuam para a consolidação da consciência ambiental 
(JACOBI, 2000) e para mitigação do impacto ambiental causado pelos resíduos da construção civil. Além disso, essa articulação viabiliza o engajamento de diferentes atores na solução dos diversos problemas verificados em Belo Horizonte e que requerem uma atuação solidária do poder público e da iniciativa privada (CAVALCANTI e CAVALCANTI, 1998).

No entanto, parece haver consenso entre os entrevistados de que os investimentos privados na área de correção e preservação ambiental precisam ser ampliados. A participação do setor privado em investimentos de infraestrutura e em outros setores tidos como estratégicos tornou-se indispensável para a consolidação das ações estatais, incluindo aí, aquelas voltadas para a preservação do meio ambiente.

Pela análise dos resultados desta pesquisa, verificou-se que o poder público, representado pela SLU, tem um papel de agente coordenador do conjunto das relações que se estabelecem entre os diversos agentes (públicos e privados) que participam direta ou indiretamente das práticas de gestão dos resíduos ora estudadas. Trata-se de uma coordenação pautada por normas institucionais, planos diretores, pela aplicação de medidas corretivas e fiscalizadoras e pela articulação de processos educacionais e de mobilização social (LUCHINI, SOUZA e PINTO, 2003).

Mesmo com todas as contribuições que a rede de políticas e práticas de gestão dos resíduos proporciona, o poder público municipal tem enfrentado uma série de problemas conjunturais e estruturais que limitam a ação dos diversos atores envolvidos. Dos diversos problemas associados às práticas de gestão de resíduos da construção civil, talvez o mais grave seja a continuação das deposições clandestinas de entulho pela cidade. Apesar de toda a estrutura montada pelo poder público municipal para coleta e deposição dos resíduos, as deposições clandestinas persistem. Os dados da tabela 1 revelam a quantidade de resíduos coletados em deposições clandestinas nos anos de 2003 e 2004.

\section{Tabelal}

Estimativa de material retirado de deposições clandestinas 2003/2004

\begin{tabular}{ccc}
\hline Ano & $\mathbf{N}^{\mathbf{o}}$ de viagens & Produção estimada $\left(\mathbf{m}^{\mathbf{3}}\right)$ \\
\hline 2003 & 24.523 & 133.155 \\
\hline 2004 & 26.444 & 132.220 \\
\hline
\end{tabular}

Fonte: Superintendência de Limpeza Urbana.

A depredação dos equipamentos de coleta, principalmente das URPVs, tem sido outro problema que o poder público municipal vem enfrentando. Por estarem situadas, na maioria das vezes, próximas de áreas geradoras de entulho (vilas e favelas), essas unidades de coleta e os equipamentos vêm sofrendo atos de vandalismo.

A implantação de novas URPVs em locais potencialmente poluidores tem sido restringida devido à escassez de áreas públicas que possam ser aproveitadas para a instalação da infra-estrutura mínima dessa unidade da rede coletora, e em razão das resistências oferecidas pela população local. Essa dificuldade tem sido agravada pela falta de informação da população que geralmente confunde a URPV com um "lixão", opondo-se à implantação dessas unidades, próximas às suas residências. Apesar do esforço de comunicação e mobilização social, as práticas de gestão ambiental precisam ser intensificadas para ampliar o nível de consciência ambiental da população, aumentando desse modo, a possibilidade de participação e engajamento de diversos atores sociais, incluindo moradores e empresários, dentre outros. Com a intensificação dessas práticas de gestão, o poder público abriria espaço para a consolidação de uma gestão ambiental que fosse de fato participativa, integrada e contínua, que compatibilizasse as atividades humanas com a preservação do patrimônio ambiental, através da ação conjugada entre poder público e sociedade (COIMBRA, 2004).

As evidências analíticas desta pesquisa revelam que a governança da rede de políticas e práticas de gestão ambiental encontra algumas restrições quanto a alguns aspectos operacionais, como aponta o coordenador do programa de reciclagem de entulho: 
Nós podemos detectar aí, que ao completar, agora, dez anos, nós temos a convicção de que é um programa setorial da limpeza urbana. Daí a necessidade de transformar em um plano integrado, ou seja, envolvendo os diversos departamentos, no próprio órgão e em outros órgãos da prefeitura. Isso não quer dizer que não há parcerias [...].

A análise desse relato revela os limites do processo de integração entre os vários órgãos do poder público municipal dificultando a consolidação da ação integrada defendida por Philippi Jr. e Bruna (2004). Para esses autores, a gestão ambiental integrada requer a participação efetiva de todos os segmentos dos setores público e privado cujas práticas de gestão cotidiana estão inter-relacionadas com a qualidade ambiental que se materializa por meio de políticas e práticas delas decorrentes. Portanto, evidencia-se a necessidade de uma maior mobilização e inserção de novos atores nas práticas de gestão de resíduos da construção civil, especialmente outros órgãos do poder público municipal. Uma maior participação desses atores proporcionaria uma maior integração, amplitude de contatos e compartilhamento de valores e objetivos, como sugere Teixeira (2002). Cabe lembrar que o poder público deve assumir o seu papel de coordenador da rede de políticas e práticas de gestão, sem, contudo, centralizar decisões e ações que requeiram a participação efetiva de outros atores (CERQUEIRA, 1992). Trata-se, portanto, de desenvolver um processo de coordenação ou governança em rede que amplie a conscientização dos atores (órgãos do poder público local, empresários, população, carroceiros e universidades, dentre outros) sobre o seu papel social, criando assim laços mais fortes que sejam capazes de dar sustentação ao desenvolvimento das políticas e práticas de gestão dos resíduos da construção civil.

\section{As contribuições econômicas, sociais e ambientais das práticas de gestão pública ambiental}

\section{Os benefícios econômicos das práticas de gestão de resíduos}

A criação da rede de coleta e reciclagem de resíduos da construção civil, discutida na seção anterior, desde a sua implantação, tem proporcionado alguns benefícios socioeconômicos significativos não só para o poder público, mas também para a sociedade. Segundo a SLU, a retirada dos resíduos da construção civil recolhidos nas URPVs tem um custo de $\mathrm{R} \$ 8,00 / \mathrm{m}^{3}$. A retirada desse mesmo material de áreas clandestinas empregando-se máquinas, caminhões e funcionários para execução da limpeza e do transporte até as usinas de reciclagem atinge o custo de $\mathrm{R} \$ 12,00 / \mathrm{m}^{3}$. A diferença de $\mathrm{R} \$ 4,00$ reais $/ \mathrm{m}^{3}$ representa uma economia para o Tesouro Municipal, pois esses recursos deixaram de ser desembolsados graças ao processo de coleta e reciclagem dos resíduos. A SLU estima que somente em 2003 o poder público economizou diretamente cerca de $\mathrm{R} \$ 154.128,00$ com a coleta realizada nas URPVs, pois esses pontos de coleta receberam cerca de $38.532 \mathrm{~m}^{3}$ de resíduos que seriam depositados de forma clandestina. Isso representou uma economia da ordem de $30 \%$, pois o poder público evitou a operação de limpeza das deposições clandestinas.

Além da redução nos custos com a implantação das URPVs, o poder público também reduziu seus custos com a utilização de material reciclado como matéria prima em suas obras públicas. A maior parte do material reciclado tem sido consumida pela própria prefeitura em suas próprias obras. A utilização desse material reciclado reduz o custo das obras em cerca de $40 \%$ a 50\%, principalmente, pelo fato das jazidas naturais estarem muito distantes das obras, ou seja, fora da cidade, o que onera muito o custo com transporte. Já as estações de reciclagem estão localizadas em pontos mais próximos, dentro do perímetro urbano. Além disso, o material reciclado tem sido usado na produção de artefatos de concreto (blocos, briquetes, meios-fios etc.) e na produção de concreto em geral, também empregado em obras de infra-estrutura pública.

As práticas de gestão de resíduos também contribuíram para a geração de empregos a um custo relativamente baixo. Nas URPVs e nas estações de reciclagem estão empregadas cerca de 55 pessoas que trabalham diretamente no processo de coleta, reciclagem e gerenciamento. As práticas de gestão dos resíduos contribuíram ainda - mesmo que de forma indireta - para a geração de renda; a exemplo dos prestadores de serviços de transportes, que ampliaram sua renda e empregaram, pelo menos, um ajudante de caminhão para auxiliar no embarque e desembarque das caçambas e na limpeza do local, caso necessário. Além dessas ocupações, as referidas práticas de gestão criaram condições para geração de renda para uma parcela significativa de carroceiros que passaram a integrar a rede de coleta dos resíduos da construção. 


\section{A gestão de resíduos como prática de inclusão socioambiental}

A história de inclusão dos carroceiros na rede de coleta de resíduos nasceu de um problema provocado por esses atores sociais que eram os grandes vilões da deposição clandestina de resíduos da construção civil. Esse diagnóstico foi feito a partir do relatório de uma consultoria realizada em Belo Horizonte, em 1993, cujo foco de intervenção foi a geração de resíduos da construção civil e a deposição clandestina desses resíduos. Esse diagnóstico constatou que aquele trabalhador que usava sua carroça de tração animal para transportar os resíduos, depositava-os em lotes vagos, córregos e em outros lugares públicos inadequados.

[...] muitas vezes, a gente pegava esse pessoal jogando, descarregando a carroça num lote vago, próximo de um curso de água, e eles simplesmente falavam: "mas eu não tenho onde descarregar, onde que eu vou jogar? Esse é meu ganha-pão, o quê que eu faço com esse produto?" Então, trazer esse pessoal pro nosso lado, ser um parceiro nosso, e dar condição dele trabalhar, entenda-se condição de trabalhar, como uma destinação adequada. (EX-COORDENADOR DO PROGRAMA DE RECICLAGEM DE ENTULHO)

Assim, em 1997, foi dado início ao processo de inserção dos carroceiros à rede receptora de resíduos. Mais especificamente, com essa prática social, o objetivo foi promover a inclusão social dos carroceiros na gestão integrada de resíduos adotada no município de Belo Horizonte. Esse processo de inclusão gerou novas oportunidades de trabalho, bem como contribuiu para a conscientização ambiental do referido grupo de trabalhadores, os quais, até então, eram marginalizados pelo poder público e pela sociedade local (JACOBI, 2002). Na realidade, o que se buscou foi uma maior aproximação entre os carroceiros e o poder público municipal. Essa aproximação se orientou pelos princípios do respeito mútuo, da cooperação e compartilhamento de informações, e do conhecimento entre as partes. Essas ações se desenvolvem pela integração de três frentes de trabalho organizadas e gerenciadas pela Prefeitura de Belo Horizonte:

- frente técnica - visar informar os carroceiros sobre a importância ambiental do programa e as conseqüências das deposições clandestinas em córregos, lotes vagos e em outros locais inadequados. Nessas informações inclui-se a conscientização dos carroceiros quanto aos benefícios da deposição de entulho ambientalmente correta e da participação deles como agentes de limpeza urbana. A frente técnica também tem sido responsável pela gestão do cadastro dos carroceiros da cidade de Belo Horizonte. A SLU cadastra e a BHtrans providencia o emplacamento, licenciamento e legalização das carroças no município. Para tanto, são expedidos certificados de registro e licenciamento da carroça e uma carteira de condutor de veículo de tração animal. Inicialmente, os carroceiros não acreditavam muito nesse trabalho. Eles desconfiavam que o cadastramento seria um instrumento de coerção e de ampliação de controle, servindo apenas para facilitar a aplicação de multas pelo poder público. Segundo Jacobi (2002), essa desconfiança deriva do lento processo de legitimação das práticas de gestão ambiental, pois requerem um período de amadurecimento para que as pessoas nelas se envolvam;

- frente social - tem o objetivo de resgatar a identidade do carroceiro como trabalhador e como cidadão pela inclusão social. Responde pela mobilização desses profissionais, motivando-os a ingressar e participar das associações. Atualmente, existem três associações de carroceiros consolidadas, lutando pelos interesses da classe. Com esse trabalho conjunto entre o poder público e as associações dos carroceiros, foi possível o reconhecimento da profissão pelo Ministério do Trabalho em Belo Horizonte. Nas ações por parte da frente social, inclui-se ainda um encontro anual para a realização de palestras, em que são abordados temas de caráter social, técnico e veterinário. Algumas regionais da prefeitura também oferecem aos carroceiros participantes das associações um curso de alfabetização. Além disso, está em fase de estudos, a implantação de um programa de saúde bucal, uma reivindicação dos próprios carroceiros;

- frente veterinária - seu propósito é cuidar da saúde do animal utilizado pelos carroceiros. Para tanto, o poder público, em parceria com a escola de veterinária da UFMG, oferece atendimento médicohospitalar contínuo e orientação sobre nutrição e saúde animal. Todos os animais dos carroceiros são marcados e registrados pelo poder público. Esse convênio também tem sido responsável pelo trabalho de inseminação artificial e melhoramento genético dos animais. A frente veterinária, em parceria com o 
serviço de zoonoses da Secretaria Municipal de Saúde, também promove a vacinação anual dos animais e registra todas as informações sobre o processo de vacinação, para um melhor controle sanitário e nutricional. Está em fase de estudos a implantação de sistemas de pastoreio e abrigo coletivo para os animais, de modo a lhes garantir maior bem-estar, particularmente com uma boa alimentação.

Pela análise dos seguintes relatos ouvidos nas entrevistas com carroceiros, e também pelos dados secundários analisados, verificou-se que a atuação da frente veterinária tem sido significativa para garantir a saúde dos animais, o que deixa seus proprietários satisfeitos.

Isso aí melhorou geral, melhorou pra todos. Tanto da oeste como das outras regionais também. Essa vacinação foi uma coisa que veio facilitar muito a nossa vida e fortalecer o animal. (CARROCEIRO 3)

[...] antes a gente tratava do animal por cabeça [...] Hoje, você vai lá com o veterinário: Ó, o que eu posso dá pro meu animal. Meu animal está sentindo uma dor de barriga; ele vai, passa um remédio. (CARROCEIRO 6)

O trabalho contínuo dessas três frentes tem proporcionado aos carroceiros o resgate de sua autoestima, preservado sua identidade como trabalhadores e, principalmente, permitido a eles o exercício da cidadania. Com a implantação das políticas e práticas de gestão de resíduos da construção civil, o trabalho desses profissionais ganhou notoriedade, passando a ser reconhecido como relevante para o combate à degradação ambiental, ganhando assim legitimidade social. Em seus relatos, os carroceiros admitem que esse programa possibilitou-lhes resgatar o orgulho pela profissão.

Faz 42 anos que eu trabalho de carroceiro. Melhorou demais da conta. Eles dão vacina, marca os animais, dá ração por mês, todas as condições pra gente trabalhar. Eu tenho treze filhos, trato tudo tirando da carroça aqui [...]. É bão pra todo mundo, bão pra família, bão pra gente melhorar a família da gente. Ganha muito mais que se a gente trabalhasse de empregado pros outros. (CARROCEIRO 2)

Com a prática de inclusão, também se proporciona ao carroceiro e à sua família a possibilidade de lazer, de convívio social, além de melhores expectativas quanto ao futuro, ampliando-se as oportunidades de vivenciarem a cidadania.

[...] todo ano a gente tem uma carroceata. A gente pode levar as crianças. É muito carroceiro que vai, e de vez em quando tem uma festa na UFMG. A gente pode levar a família, tem almoço, tem tudo. Os carroceiros de BH tudo reúne lá. Quem pode ir leva a família; então melhorou bem, até pra família da gente melhorou, porque a respeito de área de lazer, porque a gente leva a família pra festa, as criança fica tudo satisfeita. (CARROCEIRO 5)

A análise desse relato reforça a tese de Junqueira R, (1998). Para esse autor, somente uma política não basta para resolver problemas sociais. Estes requerem a ação integrada das diversas políticas públicas que articulam saberes e experiências que produzem efeito sinérgico em situações de desenvolvimento e inclusão social. No contexto estudado, a ação integrada das três frentes de trabalho produziu um efeito sinérgico de inclusão social dos carroceiros.

\section{A produção de artefatos de concreto como forma de inclusão socioeconômica}

Outra contribuição socioeconômica das políticas e práticas de gestão dos resíduos da construção civil foi a implementação da fábrica de produção de artefatos de concreto que utiliza agregados reciclados como matéria prima. Essa fábrica foi denominada por seus idealizadores de Ecobloco. Trata-se de um projeto de inclusão social de pessoas que tinham uma trajetória de rua; ou seja, pessoas que, por um motivo qualquer, migraram para Belo Horizonte e não exerceram plenamente sua cidadania, dada a sua exclusão do mercado de trabalho.

A idéia do projeto Ecobloco surgiu de um trabalho escolar preparado por três alunos do Sebrae. Esse trabalho focava a utilização de material da construção civil reciclado por uma empresa, para a fabricação de artefatos de concreto. O poder público municipal decidiu apoiar a idéia e, posteriormente, o Ministério do Desenvolvimento Social e Combate à Fome cedeu os recursos para financiar a implementação do projeto. Inicialmente, um grupo 
de 10 pessoas foi capacitado para o trabalho com o acompanhamento de técnicos e da assistência social. O projeto tem sido gerenciado por um profissional com experiência acadêmica, cuja função é treinar as pessoas selecionadas e coordenar a produção e comercialização dos artefatos de concreto produzidos pela Ecobloco, que foi inaugurada em junho de 2004 e está instalada na Estação de Reciclagem Estoril.

Atualmente, a fábrica confecciona blocos de concreto (carro-chefe da produção), para atender à crescente demanda do mercado. Todavia, há planos de serem fabricados outros artefatos de concreto. Os blocos de concreto produzidos são ensaiados, ou seja, passam por análises laboratoriais para controle de qualidade e checagem se atendem às normas da Associação Brasileira de Normas Técnicas (ABNT). Essas análises são feitas gratuitamente por uma empresa especializada que tem apoiado o projeto. A produção e a comercialização desses blocos de concreto é a principal fonte de recursos. Além de sustentar financeiramente o projeto, o lucro obtido com a comercialização dos artefatos de concreto é dividido entre os 10 participantes que não mantêm contratos formais de trabalho com a Ecobloco. Trata-se de uma empresa de participação que visa à inclusão social.

Pelas análises feitas, notou-se que esse projeto, além de permitir a efetiva inclusão social desses integrantes, gera emprego e renda, contribuindo para reduzir o impacto ambiental por meio da substituição de recursos nãorenováveis por agregados reciclados. Porém, falta ainda a divulgação da qualidade dos blocos de concreto produzidos pela Ecobloco e a conscientização da população local quanto ao uso de produtos ambientalmente compatíveis.

A continuidade das práticas de inclusão social discutidas anteriormente depende da articulação de novas formas de interação, do desenvolvimento de ações educativas ambientais que ampliem o nível de conscientização da população e da adoção de novas tecnologias de gestão sustentáveis de resíduos da construção civil. No entanto, verificou-se que a rede de políticas e práticas de gestão desses resíduos implementadas pelo poder público em Belo Horizonte produziu efeitos sinérgicos significativos para o meio ambiente. Esses efeitos serão objeto de reflexão na próxima subseção.

\section{As contribuições ambientais das práticas de gestão de resíduos}

Além das contribuições socioeconômicas discutidas anteriormente, a policy network coordenada pelo poder público municipal tem produzido um "conjunto de repercussões ambientais" que vão da coleta dos resíduos da construção civil, passando pela reciclagem e uso dos agregados reciclados, até a melhoria da paisagem urbana. É oportuno destacar que essa rede de políticas e práticas de gestão de resíduos implementadas pelo poder público municipal em Belo Horizonte reduziu o impacto ambiental através da reciclagem de cerca de 720 mil toneladas no período 1996-2004.

A implantação das URPVs em locais estratégicos do município tem contribuído para melhorar o controle ambiental, bem como inibir deposições clandestinas de resíduos da construção civil por parte dos geradores e transportadores. A existência dessas unidades de coleta chama a atenção da população e dos geradores de resíduos para a necessidade de depositá-los de forma ambientalmente compatível, evitando que esse material seja depositado em lotes vagos, na beira de córregos, mananciais e em outros locais, contribuindo assim para manter a cidade mais limpa. Além disso, o despejo indiscriminado desse resíduo pela malha urbana influencia a deposição de outros tipos de resíduos, colocando em risco a saúde pública.

Com a implantação da rede de coleta e reciclagem, foi reduzida a distância de transporte entre a geração dos resíduos e sua deposição final, melhorando o fluxo do trânsito local, o que por sua vez reduz a poluição atmosférica. Além disso, com a deposição ambientalmente correta nas URPVs e estações de reciclagem, ampliou-se a vida útil do aterro sanitário local que passou a absorver um menor volume de resíduos da construção civil. Outro benefício do ponto de vista ambiental das práticas de gestão dos resíduos tem sido a preservação das jazidas naturais de recursos não-renováveis. A produção de agregados provenientes da reciclagem substitui materiais da construção civil como areia, brita e o minério de ferro, evitando que sejam extraídos diretamente das jazidas naturais, aumentando a vida útil dessas reservas e evitando a degradação de áreas próximas. 
A inclusão social dos carroceiros na rede de coleta de resíduos tem provocado fortes mudanças comportamentais nesses atores, que demonstraram nas entrevistas maior nível de conscientização ambiental e comprometimento com a melhoria da qualidade de vida e da limpeza urbana.

[...] se não tivesse URPV, o que a gente estaria fazendo? Igual fazia antigamente. Não tinha URPV, jogava no lote, jogava nos buraco, aterrando [...] hoje já não tá tendo mais. Praticamente, você não vê isso hoje acontecer. Você não vê máquina da prefeitura na beira de córrego. Antigamente, aterrava os córrego tudo. Por que aterrava? Porque a gente jogava nas cabeceira, jogava nos lote; aí a chuva vinha levava, aterrava, a prefeitura tava lá com as máquina, escavadeira tirando, os operário que tinha [...]. (CARROCEIRO 6)

Pela análise desse relato, verifica-se que com as práticas de educação ambiental e mobilização social, a percepção dos carroceiros sobre o seu papel social se modificou, especificamente, no que diz respeito a sua atuação pela preservação do meio ambiente, com redução do impacto causado pelos resíduos da construção nos mananciais, nos lotes vagos, nas margens de córregos e em outras áreas. A contribuição ambiental dessa prática de inclusão social também se manifesta pelo crescimento da quantidade de material coletado por carroceiros (tabela 2). Entre 1997 e 2001, esse crescimento alcançou a marca de quase 200\%, evitando, assim, o despejo de mais de 352 mil toneladas de resíduos no meio ambiente.

Tabela 2

Quantidade de material recebido nas URPVs em toneladas

(1997-2001)

\begin{tabular}{cccccc}
\hline ANO & $\mathbf{1 9 9 7}$ & $\mathbf{1 9 9 8}$ & $\mathbf{1 9 9 9}$ & $\mathbf{2 0 0 0}$ & $\mathbf{2 0 0 1}$ \\
\hline Quantidade & 36.577 & 53.674 & 70.277 & 95.212 & 97.000 \\
\hline
\end{tabular}

Fonte: SLU.

As análises dos resultados dessa pesquisa evidenciaram que a policy network de gestão de resíduos espelha-se em algumas diretrizes como a da cooperação estabelecida entre governo, iniciativa privada e demais setores da sociedade pelo desenvolvimento planejado da cidade. O objetivo é corrigir as distorções decorrentes da urbanização e combater seus efeitos negativos sobre o meio ambiente, ordenando o uso do solo e evitando a poluição.

\section{Considerações finais}

Este trabalho teve como objetivo estudar as práticas de gestão de resíduos da construção civil implementadas pelo poder público municipal em Belo Horizonte. Para tanto, foi empregado o método de pesquisa descritiva, articulado com o processo de triangulação das técnicas de coleta de dados. A natureza da problemática estudada exigiu a sistematização de um quadro de referências que incluiu algumas reflexões teóricas acerca da relação entre Estado, políticas públicas e gestão ambiental. Nessa reflexão, destacou-se como a reforma do Estado incorporou a lógica de gestão que vem estimulando a democratização do poder público e a descentralização administrativa. Esse processo vem conferindo maior autonomia, mas também atribuído maiores responsabilidades aos municípios, especialmente, quanto à formulação e execução de políticas de gestão ambiental. Assim, os municípios passaram a empreender ações de proteção e mitigação do impacto ambiental causado por atividades produtivas e serviços locais, a exemplo da cidade de Belo Horizonte.

Pelas análises dos resultados desta pesquisa, verificou-se que da formulação e implementação das políticas públicas ambientais e práticas de gestão de resíduos da construção civil, originou-se uma policy netwok que envolve a interação entre diversos atores sociais públicos e privados e mantém um padrão de relações interdependentes que servem de referência para a concretização das práticas de gestão desses resíduos. O poder público, representado pela SLU, exerce um papel de agente coordenador do conjunto das relações estabelecidas entre esses diversos atores que participam direta ou indiretamente das políticas e práticas de gestão dos resíduos. Tra- 
ta-se de uma coordenação pautada por normas institucionais, planos diretores, pela aplicação de medidas corretivas e fiscalizadoras, e pela articulação de processos educacionais e de mobilização social.

A implantação de uma rede de política pública de gestão dos resíduos da construção civil demandou a implantação de uma infra-estrutura própria e a instalação de equipamentos em diferentes pontos estratégicos de Belo Horizonte. Associado a essa infra-estrutura, o poder público formulou e implementou - levando em consideração o saber e a cultura urbana locais - um conjunto de práticas de gestão, de educação ambiental e de mobilização social determinantes para a mudança de comportamento da população em geral e de diversos atores envolvidos no processo de gestão dos resíduos da construção civil investigado neste estudo. Mais especificamente, as referidas práticas de gestão de resíduos apresentaram duas dimensões: uma física e outra comportamental. A primeira dimensão foi denominada pelo poder público de "rede de coleta e reciclagem", composta por 23 URPVs e duas estações de reciclagem de resíduos. A segunda, chamada "rede programática", envolve as práticas de comunicação e mobilização social, de recuperação de áreas degradadas, e de monitoramento e fiscalização ambiental. Quando analisadas de forma integrada, essas duas dimensões evidenciam que o poder público construiu uma lógica de ação com a referida policy network, cujas particularidades trazem os seguintes benefícios:

- maior captação de recursos financeiros na iniciativa privada, que tem se envolvido em algumas práticas de gestão de resíduos;

- implantação de tecnologia via satélite para identificação e controle das deposições clandestinas e de outros problemas ambientais urbanos;

- maior consciência política e ambiental da população em geral e dos próprios atores integrantes da rede;

- inclusão social de cidadãos, por meio da geração de emprego e renda;

- desenvolvimento de estudos para a melhoria da qualidade do material reciclado; e

- realização de pesquisas para o desenvolvimento de novos produtos de resíduos da construção civil, como alternativa de materiais de qualidade e de menor custo para o mercado.

Além desses benefícios, as análises empreendidas ao longo deste estudo revelaram outras contribuições socioeconômicas das práticas de gestão dos resíduos da construção civil. A utilização da rede de coleta pelos geradores e transportadores reduziu custos operacionais, tanto do poder público como dos próprios geradores e transportadores que aumentaram a eficiência da sua logística de transporte. A natureza social das práticas de gestão de resíduos da construção civil permitiu que novas oportunidades de trabalho e renda fossem geradas para os carroceiros e integrantes da empresa de participação social Ecobloco. Esse processo de inclusão promoveu o resgate da auto-estima dos referidos cidadãos, ampliando a sua consciência ambiental e melhorando a sua qualidade de vida.

Evidenciou-se ainda que as referidas práticas, além de contribuírem para a limpeza da cidade, tem proporcionado os seguintes benefícios ambientais:

- inibição da deposição desses resíduos em lotes vagos, beira de córregos, mananciais e em outros locais inadequados;

- preservação da saúde pública;

- melhoria da rede de drenagem urbana, evitando o entupimento de galerias e bocas de lobo;

- prolongamento da vida útil do aterro sanitário da cidade, pois ele deixa de ser o destino final dos resíduos da construção civil; e

- preservação das jazidas de recursos naturais não-renováveis pela utilização dos agregados produzidos com a reciclagem desses resíduos.

Contudo, foi observado que, apesar das contribuições socioeconômicas e ambientais da rede de políticas e práticas de gestão estudadas, o poder público municipal tem enfrentado uma série de complicadores conjunturais e 
estruturais que limitam a sua eficiência e a das ações individuais e coletivas dos diversos atores nelas envolvidos. Dessas limitações, destacam-se:

- a falta de espaço público para a implantação de novas URPVs;

- persistência das deposições clandestinas dos resíduos da construção civil;

- degradação da infra-estrutura de coleta de resíduos pela população local;

- limitações associadas à integração entre os órgãos do poder público municipal;

- práticas de monitoramento e fiscalização ambiental limitadas pelo pequeno número de fiscais públicos disponíveis para essas atividades; e

- os obstáculos associados à capacidade de comunicação e mobilização social da população e de outros atores sociais.

Acredita-se que a realização deste estudo possa contribuir para o avanço do conhecimento na área de gestão ambiental, especialmente, no que diz respeito às práticas de administração de resíduos oriundos da indústria da construção civil. A expectativa também é de que, ao retratar uma experiência de gestão ambiental pública bemsucedida, as considerações aqui reunidas possam servir de elemento indutor e de referência para o poder público de outras cidades onde haja interesse na implementação de políticas e práticas de gestão dos resíduos da construção civil. É relevante destacar que em qualquer trabalho de pesquisa não se esgota e nem se revelam as múltiplas dimensões de uma dada realidade. Assim, é sugerida uma agenda de estudos que envolva:

- a identificação e análise da dimensão política das redes de políticas públicas voltadas para o meio ambiente, particularizando as relações de poder e os conflitos de interesses entre os atores sociais que integram essas redes;

- o estudo da viabilidade da implementação de uma policy network de gestão de resíduos da construção civil, através de um consórcio organizado por municípios vizinhos;

- a investigação das medidas adotadas pela indústria da construção civil para mitigar a geração de resíduos e o impacto ambiental resultante; $\mathrm{e}$

- a valoração ambiental dos benefícios proporcionados pelas políticas e práticas de gestão dos resíduos da construção civil na cidade de Belo Horizonte. 


\section{Referências}

ALENCAR, E. Métodos de pesquisa nas organizações. Lavras: UFLA/Faepe, 2000. 109p.

BARAT, J. 0 Estado brasileiro como refém das políticas de curto prazo. Cadernos Fundap, São Paulo, n.22. p.62-68, 2001.

BAVA, S. C. Democracia e poder local. Polis, Instituto de Estudos, Formação e Assessoria em Políticas Sociais, n.14, p.3-9, 1994.

BELO HORIZONTE. Prefeitura Municipal. Disponivel em: <http://www.pbh.gov.br> Acesso em: 27 jan. 2005.

BOGDAN, R. C.; BIKLEN, S. K. Investigação qualitativa em educação. Porto: Porto Editora, 1994. 335p.

BORN, S. M.; SONZOGNI, W. Towards integrated environmental management: strengthening the conceptualization. Environmental Management, New York, v.19, n.2, p.167-183, 1995.

BÖZEL, T. A. Organizing Babylon - on the different conceptions of policy networks. Public Administration, v.76, p.253-273, Summer 1998.

BRITO, M. J. Mudança e cultura organizacional: a construção social de um novo modelo de gestão de P\&D na Embrapa. 2000. Tese (Doutorado em Administração) - Universidade de São Paulo, São Paulo, 2000.

CAVALCANTI, B. S.; CAVALCANTI, I. Explorando as novas fronteiras da descentralização e da participação: o caso da gestão integrada dos recursos hídricos no Brasil. Revista de Administração Pública, Rio de Janeiro, v.32, n.5, p.81-97, set./out. 1998.

CERQUEIRA, F. Formação de recursos humanos para a gestão ambiental. Revista de Administração Pública, Rio de Janeiro, v.26, n.1, p.5055, jan./mar. 1992.

COIMBRA, J. A. A. Linguagem e percepção ambiental. In: PHILIPPI JR. et al. Curso de gestão ambiental. Barueri: Manole, 2004. v.15.

DEMAJOROVIC, J. Meio ambiente e resíduos sólidos. 1994. Dissertação (Mestrado) - Fundação Getulio Vargas, São Paulo, 1994.

EGRI C. P.; PINFIELD, L. T. As organizações e a biosfera: ecologia e meio ambiente. In: CLEGG, S. et al. Modelos de análise e novas questões em estudos organizacionais. Handbook de Estudos Organizacionais. São Paulo: Atlas, 1998. v.14.

ESCOLA POLITÉCNICA DA UNIVERSIDADE DE SÃO PAULO (Epusp). Estudo prospectivo da cadeia da construção civil. São Paulo, v.1, mar. 2002.

FARAH, M. F. S. Gestão pública e cidadania: iniciativas inovadoras na administração subnacional no Brasil. Revista de Administração Pública, Rio de Janeiro, v.31, n.4, p.126-56, jul./ago. 1997.

FERREIRA, L. C. A Busca de alternativas de sustentabilidade no poder local. In: FERREIRA, L. C.; VIOLA, E. (Org.). Incertezas de sustentabilidade na globalização. Campinas: Editora da Unicamp, 1996. p.133-160.

FREY, K. Políticas públicas: um debate conceitual e reflexões referentes à prática da análise de políticas públicas no Brasil. Planejamento e Políticas Públicas, n.21, jun. 2000. Disponivel em: <http://www.ipea.gov.br>. Acesso em: 26 maio 2005.

FRIEDER, J. Approaching sustainability: integrated environmental management and New Zealand's Resource Management Act. lan Axford Fellowships in Public Policy. New Zealand, 1997.

FUNDAÇÃO JOÃO PINHEIRO. Boletim Pesquisa de Emprego e Desemprego na Região Metropolitana de Belo Horizonte (PED/RMBH). Belo Horizonte, 2004a. Disponivel em: <http://www.fjp.gov.br>. Acesso em: 2 fev. 2005.

Informativo CEI - Produto Interno Bruto de Minas Gerais 2003. Belo Horizonte, jun. 2004b. Disponível em: $<$ http://www.fjp.gov.br>. Acesso em: 2 fev. 2005.

GRUMBINE, R. E. What is ecosystem management? Conservation Biology, v.8, n.1, p.27-38, 1994.

JACOBI, P. Meio ambiente e redes sociais: dimensões intersetoriais e complexidade na articulação de práticas coletivas. Revista de Administração Pública, Rio de Janeiro, v.34, n.6, p.131-158, nov./dez. 2000.

. Meio ambiente urbano e sustentabilidade: alguns elementos para a reflexão. In: CAVALCANTI, C. (Org.). Meio ambiente, desenvolvimento sustentável e políticas públicas. 4.ed. São Paulo: Cortez; Recife: Fundação Joaquim Nabuco, 2002. p.384-390. 
JOHN, V. M. Reciclagem de resíduos na construção civil: contribuição para uma metodologia de pesquisa e desenvolvimento. 2000. 113p. Tese (Livre docência) - Escola Politécnica da Universidade de São Paulo, 2000.

; AGOPYAN, V. Reciclagem de residuos da construção. In: SEMINÁRIO RECICLAGEM DE RESÍDUOS SÓLIDOS DOMÉSTICOS, 2000, São Paulo. Disponivel em: <http://www.recycle.pcc.usp.br/artigos1.htm>. Acesso em 27 jan. 2005.

JUNQUEIRA, L. A. P. Descentralização e intersetorialidade: a construção de um modelo de gestão municipal. Revista de Administração Pública, Rio de Janeiro, v.32, n.2, p.11-22, mar./abr. 1998.

JUNQUEIRA, R. G. P. A intersetorialidade do ponto de vista da educação ambiental: um estudo de caso. Revista de Administração Pública, Rio de Janeiro, v.32, n.2, p.79-91, mar./abr. 1998.

KLIJN, E. Policy networks: an overview. Managing complex networks. London: Sage, 1998.

LAVILLE, C.; DIONNE, J. A construção do saber. Belo Horizonte: UFMG, 1999. 279p.

LUCHINI, A. M.; SOUZA, M. D.; PINTO, A. L. Aportes e limites da perspectiva de redes de políticas públicas: o caso da gestão da água. Caderno de Pesquisas em Administração. São Paulo, v.10. n.2, p.87-94, abr./jun. 2003.

MARGERUM, R. D. Integrated environmental management: the foundations for successful practice. Environmental Management, New York, v.24, n.2, p.151-166, Sept. 1999.

; BORN, S. M. Integrated environmental management: moving from theory to practice. Journal of Environmental Planning and Management, v.38, n.3, p.371-391, 1995.

A coordination diagnostic for improving integrated environmental management. Journal of Environmental Planning and Management, v.43, n.1, p.5-21, jan. 2000.

MELO, M. A. Crise federativa, guerra fiscal e "hobbesianismo municipal": efeitos perversos da descentralização? São Paulo em Perspectiva, São Paulo, v.10, n.3, p.11-20, 1996.

MENEZES, C. L. Emergência e evolução da política ambiental urbana no Brasil: do Estado Novo à Nova República. Revista de Administração Pública, Rio de Janeiro, v.31, n.1, p.70-95, jan./fev. 1997.

MILLER, Hugh T. Post-progressive public administration: lessons from policy networks. Public Administration Review, v.54, n.4, p.378-386, July/Aug. 1994.

MITCHELL, B.; HOLLICK, M. Integrated catchment management in Western Australia: transition from concept to implementation. Environmental Management, New York, v.17, n.6, p.735-743, 1993.

MOURA, S. A construção de redes públicas na gestão local: algumas tendências recentes. Revista de Administração Contemporânea, São Paulo, v.2, n.1, p.67-85, jan./abr. 1998.

NUNESMAIA, M. F. A gestão de resíduos urbanos e suas limitações. Revista Baiana de Tecnologia, Bahia, v.17, n.1, p.1120-129, jan./abr. 2000.

PACHECO, R. S. Administração pública gerencial: desafios e oportunidades para os municípios brasileiros. In: O MUNICIPIO no século XXI: cenários e perspectivas. São Paulo: Fundação Prefeito Faria Lima, 1999. p.39-49.

PEIXOTO, R. D. et. al. A verba que vai para o lixo: investimento ou desperdício? Revista de Administração Pública, Rio de Janeiro, v.33, n.6, p.191-226, nov./dez. 1999.

PELICIONI, A. F. Trajetória do movimento ambientalista. In: PHILIPPI JR. et al. Curso de gestão ambiental. Barueri: Manole, 2004. v.12.

PEREIRA, L. C. B. A reforma do estado dos anos 90: lógica e mecanismos de controle. Ministério da Administração Federal e Reforma do Estado. Brasilia. Cadernos Mare da Reforma do Estado, 1997. v.1, 58p.

Uma reforma gerencial da administração pública no Brasil. Revista do Serviço Público, Fundação Escola Nacional de Administração Pública, Brasilia, ano 49, n.1, p.5-42, jan./mar. 1998.

PHILIPPI JR., A.; BRUNA, G. C. Política e gestão ambiental. In: PHILIPPI JR., et al. Curso de gestão ambiental. Barueri: Manole, 2004. v.18. 
PINTO, T. P. Metodologia para a gestão diferenciada de resíduos sólidos da construção urbana. 1999. 189p. Tese (Doutorado em Engenharia Civil) - Escola Politécnica da Universidade de São Paulo, 1999.

SILVA, J. A. O. 0 município e a proteção ambiental. Revista de Administração Pública, Rio de Janeiro, v.26, n.3, p.88-106, jul./set. 1992.

SILVA, S. T. Políticas públicas e estratégias de sustentabilidade urbana. In: SÉRIE GRANDES Eventos - Meio Ambiente. Escola Superior do Ministério Público da União. Brasilia, 2004. v.1. Disponível em: <http://www.esmpu.gov.br/publicacoes/meioambiente>.

SIQUEIRA, M. M. Redes sociais na gestão de serviços públicos. Revista de Administração Pública, Rio de Janeiro, v.34, n.6, p.179-98, nov./dez. 2000.

SLOCOMBE, D. S. Environmental planning, ecosystem science and ecosystem approaches for integrating environment and development. Environmental Management, New York, v.17, n.3, p.289-303, 1993.

TEIXEIRA, S. M. F. 0 desafio da gestão das redes de políticas. In: CONGRESO INTERNACIONAL DEL CLAD SOBRE LA REFORMA DEL ESTADO Y DE LA ADMINISTRACIÓN PÚBLICA, 7., 8-11 oct. 2002, Lisboa, Portugal.

THATCHER, M. The development of policy network analyses: from modest origins to overarching frameworks. Journal of Theoretical Politics, v.10, n.4, p.389-416, 1998.

TOLOSA, H. C. Os novos desafios da política urbana na era do real. Planejamento e Políticas Públicas, n.15, jun. 1997. 